\title{
The Syntactic Cartography of the TP Layer in Minimalism
}

\author{
Feras Saeed ${ }^{1}$ \\ ${ }^{1}$ Qassim University, Kingdom of Saudi Arabia \\ Correspondence: Feras Saeed, Unaizah Community College, Qassim University, Unaizah, KSA, P. O. Box \\ 51911-4394. E-mail: ferasaeed@yahoo.com
}

Received: December 25, 2014 Accepted: January 20, 2015 Online Published: March 29, 2015

doi:10.5539/ijel.v5n2p79 URL: http://dx.doi.org/10.5539/ijel.v5n2p79

\begin{abstract}
Recent analyses of word order in Standard Arabic and the regional varieties of Arabic have assumed that the postverbal subject in the VSO word order in these languages is actually in-situ in its base position in spec-vP (Fassi Fehri, 1993; Ouhalla, 1994; Shlonsky, 1997; Benmamoun, 2000 et al.). In this paper, I provide an alternative analysis in which the postverbal subject in the VSO word order is assumed to have vacated its base-position in spec-vP and moved to the left of the $\mathrm{vP}$ projection. I take this new position of the postverbal subject to be the specifier position of the functional head Subj that heads a projection between vP and TP (Kayne, 2000; Belletti, 2004; Ordonez, 2005). Arguments that support this assumption come from the comparison of Standard Arabic and Sana'ani Arabic, through examining the distribution of postverbal subjects with respect to quantifiers, adverbs, pronominal clitics and restructuring contexts. This paper introduces new evidence to the effect that a detailed cartography of the postverbal area in these languages can provide a relatively minimal account for parametric differences in postverbal subject position(s) in other related languages.
\end{abstract}

Keywords: cartography, TP layer, postverbal subject, quantifiers, adverbs, restructuring, pronominal clitics

\section{Introduction}

Standard Arabic has two main word orders where the subject can either precede or follow the verb:

1) katab-a 1-awlaad-u r-risaalat-a

wrote-sg the-boys-nom the-letter-acc

'The boys wrote the letter'

2) al-awalaad-u katab-uu r-risaalat-a

the-boys-nom wrote-pl the-letter-acc

'The boys wrote the letter'

Arguing in favour of the SVO to be the unmarked word order in this language seems tempting, since this order can be obtained in-situ, without appealing to movement. Following Chomsky's $(2000,2001,2005)$ theory of formal feature valuation, one can assume that the inflectional head T in SVO order values its formal features against the vP-internal DP and, as a reflex, assigns the Case of the subject DP in-situ.

Another valid option to account for the VSO order is to assume that the verb is raised into a higher head, presumably the head T. Two problematic issues will arise at this juncture. The first issue has to do with the motivation for verb movement. If formal features, tense, and Case can all be valued via Agree in-situ in the SVO order, what else can motivate verb movement in VSO order? The second issue is the subject-verb agreement asymmetry. The verb loses its plural number morphology when it moves over the subject in VSO order. There has been no satisfactory explanation for these two issues which pose a problem for the claim that SVO is the unmarked word order in Standard Arabic.

It is argued that Standard Arabic is a morphologically rich language where the verb encodes information of more than one paradigm at the same time (Fassi Fehri, 1993). This morphological richness explains the fact that the verb in this language needs to move into higher heads like Tense, Agreement, Aspect, Mood, etc (Fassi Fehri, 1993; Ouhalla, 1994). However, assuming that the verb moves outside the vP shell only in VSO word order is dubious at best. If the verb moves past the subject in VSO order in order to license its rich morphology, how does the verb license its morphological features in SVO word order? 
This has led modern Arab linguists to assume that the unmarked word order in Standard Arabic is VSO and the alternative order SVO is derived via subject movement; hence verb movement in Standard Arabic is not optional since the verb has to move in both word orders (Fassi Fehri, 1993; Ouhalla, 1994; Shlonsky, 1997; Benmamoun, 2000 et al.). Therefore, the optionality is actually in subject movement, i.e., whether the subject stays in-situ in spec-vP or moves to spec-TP. In an unpublished manuscript, I tackle this optionality in terms of formal feature availability on the functional head T, whether phi-complete or phi-defective, and the motivation for the EPP feature. The proposed analysis accounts for both subject movement as well as subject-verb agreement asymmetry at once.

After establishing that the verb in Standard Arabic must always move outside the vP projection and, probably, left-adjoin the head T, I examine in this paper the position(s) of the postverbal subject in this language, assuming that the area above the vP projection (what I term here as the TP layer) can be actually mapped and dissected. The TP layer may include other functional heads like AdvP, ModP, and SubjP. In this paper, I try to map this syntactic layer through tracing all the possible positions a postverbal subject can appear in.

\section{Postverbal Subjects in Standard Arabic}

Postverbal subjects in Standard Arabic can surface in more than one syntactic position when they appear with other complements like DPs and PPs:

3) katab-a Sayf-un ar-resaalat-a

wrote-m Sayf-nom letter-acc

'Sayf wrote a letter'

4) katab-a r-resaalat-a Sayf-un

wrote-m letter-acc Sayf-nom

'Sayf wrote a letter'

5) takallam-at Belgees-u a'n at-tajrubat-i

talked-f Belgees-nom about the-experiment-gen

'Belgees talked about the experiment'

6) takallam-at a'n at-tajrubat-i Belgees-u

talked-f about the-experiment-gen Belgees-nom

'Belgees talked about the experiment'

This alternation in position does not occur exclusively with argumental complements. Postverbal subjects in this language can also precede or follow embedded nonfinite clauses that appear with some modals:

7) lam yastate Sayf an yanaama

Neg could Sayf to sleep

'Sayf could not sleep'

8) lam yastate an yanaama Sayf

Neg could to sleep Sayf

'Sayf could not sleep'

Sana'ani Arabic behaves in a similar way when it comes to the postverbal subject position and its relation with other complements. The postverbal subject in Sana'ani Arabic can precede or follow DP/PP complements:

9) shereb-at Belgees shahi ams

drank-f Belgees tea yesterday

'Belgees had tea yesterday'

10) shereb-at shahi Belgees ams

drank-f tea Belgees ams

'Belgees had tea yesterday' 
11) reje Sayf min ar-rehleh ams

returned Sayf from the-trip yesterday

'Sayf returned from the trip yesterday'

12) reje min ar-rehleh Sayf ams

returned from the-trip Sayf yesterday

'Sayf returned from the trip yesterday'

It has been assumed in the literature (Ordonez, 1998; Alexiadou \& Anagnostopoulou, 2001) that subjects that precede complements are actually in their thematic position in spec-vP higher than the other complements (Ordonez, 2005):

13) $\left[\begin{array}{llll}\mathrm{vP} & \mathrm{sub} & {[\mathrm{VP}} & \mathrm{DP} / \mathrm{PP}\end{array}\right]$

Therefore, in the alternative order where the subject follows other complements, it is assumed that the subject stays in-situ and the complements undergo displacement to a position higher than the subject:

14) $\left[\begin{array}{lllll}\mathrm{vP} & \mathrm{DP} / \mathrm{PP}_{t} & \mathrm{sub} & {[\mathrm{VP}} & t\end{array}\right]$

In this paper, I look at an alternative analysis where the subject in ( $3 \& 5)$ and $(9 \& 11)$ above is assumed to have left its thematic position in spec-vP and moved to the specifier position of a higher functional category 'SubjP' (Kayne, 2000; Belleti, 2004; Ordonez, 2005):

15) $\left[\right.$ SubjP $\quad \operatorname{sub}_{t} \quad\left[\begin{array}{lll}\mathrm{vP} & { }_{t} & \mathrm{DP} / \mathrm{PP}\end{array}\right]$

Under this analysis, the subject in (15) still precedes other complements, but now it is not in its thematic position in spec-vP anymore.

The main question here is whether the subjects in (3-6 \& 9-12) are all in-situ in spec-vP in those alternating orders or not. While the traditional proposal assumes that DP and PP complements can move freely past the subject which stays in-situ, this paper assumes that the other competing proposal in (15) can actually account for this alternative word order if two subject positions are involved. In her analysis of postverbal subjects in Italian, Belletti has proposed that there are two available positions for the subject: i) a higher SubjP; and ii) a lower FocusP. Therefore, the alternating order in (3-6 \& 9-12) is the result of whether the subject is in spec-SubjP or spec-FocusP.

In this paper, I examine this alternating order of the postverbal subject in Standard Arabic and Sana'ani Arabic and show that the proposed analysis in (15) is superior to the in-situ analysis. Following Belletti (2004) and Ordonez (2005), I adopt the SubjP analysis for the Standard Arabic and Sana'ani Arabic data where I assume the postverbal subject in a verb-subject-complement order to be in spec-SubjP rather than spec-vP. In the next sections I look into empirical evidence that shows that this is the case for Standard Arabic and Sana'ani Arabic subjects when they precede complement DPs/PPs.

\section{Quantifiers and the Position of the Subject}

Examining the position of postverbal subjects with relation to complements that are usually considered in the literature to have moved to the left of vP, like quantifiers, can lend support to our assumption that subjects actually occupy a position higher than the $\mathrm{vP}$ projection.

Kayne (1975) examines the distribution of the quantifier tout in French and concludes that it obligatorily moves to the left of past participles:

16) Jean a [tout] mange [*tout].

Jean has all eaten [*all]

'Jean has eaten everything'

The example (16) above shows that the quantifier complement must undergo movement to the left of the past participle verb in order for the sentence to be grammatical.

Ordonez (2005) examines the distribution of the quantifier todo in Spanish and notes that this language cannot have the same order like French. The reason quantifier complements cannot follow past participles in Spanish is ascribed to the assumption that these verbs must have moved further to the left of the moved quantifier. However, Ordonez observes that the quantifier todo behaves differently when coupled with manner adverbs like bien and mal: 
17) (lo) hace todo bien EL.

It make all well $\mathrm{He}$

'Pedro makes it all well'

18) lo ve todo claro EL.

It sees all clear $\mathrm{He}$

'Pedro sees it all clearly'

He points out that the alternative order between the quantifier and manner adverb will render ungrammatical sentences:

19) *aqui (lo) hace bien todo EL.

here it makes well all $\mathrm{He}$

20) *aqui lo ve claro todo EL.

here it sees clear all He.

Ordonez (2005) argues that the contrast in the examples above shows that the object quantifier must move to the left of manner adverbs. His next step was to examine the position of these quantifier objects, which is higher than $\mathrm{vP}$, with respect to subject floating quantifiers:

21) las estudiantes lo hacen todas todo bien.

the students-F it do all-F everything well

'The students all do everything well'

22) *las estudiantes lo hacen todo todas bien.

the studetns-F it do everything all-F well

'The students all do everything well'

23) mis companeros lo hacen ambos todo bien.

my classmates it do both all well

'My classmates both do everything well'

24) *mis companeros lo hacen todo ambos bien.

my classmates it do all both well

'My classmates both do everything well'

Similar to the behavior of floating quantifiers, he argues that subjects must precede the quantifier todo in the context below:

25) ayer lo hizo/encontro Juan todo bien.

yesterday it did/found Juan all well

'Yesterday Juan did/found everything well'

26) *ayer lo hizo/encontro todo Juan bien.

yesterday it did/found all Juan well

'Yesterday Juan did/found everything well'

Ordonez argues that the examples above show that subject floating quantifiers must precede object quantifiers in Spanish. He concludes that subjects are not in-situ in these examples but positioned to the left of adverbs and the moved quantifier todo. Therefore, he assumes that the subject in Spanish must have moved to the specifier of SubjP which is higher than the position of the quantifier:

27) [Subjp $\operatorname{Juan}_{\mathrm{i}}\left[\right.$ todo [ bien $\left[\begin{array}{lll}\mathrm{vP} & \mathrm{t}_{\mathrm{i}} & ]\end{array}\right]$

In Standard Arabic, the quantifier jamiaha 'all' usually precedes manner adverbs, indicating that it must have moved to the left of the manner adverbs which, in turn, are higher than the vP projection: 
28) aslaha-ha Sayf jamiaha bimahara

fixed-it Sayf all skillfully

'Sayf fixed it all skillfully'

29) ? aslaha-ha Sayf bimahara jamiaha

fixed-it Sayf skillfully all

'Sayf fixed it all skillfully'

30) akalat-ha Belgees jamiaha binaham

ate-it Belgees all greedily

'Belgees ate it all greedily'

31) ?? akalat-ha Belgees binaham jamiaha

ate-it Belgees greedily all

'Belgees ate it all greedily'

Similarly, in Sana'ani Arabic, the quantifier kulleha 'all' precedes manner adverbs, indicating that it must have moved to a position higher than the base position of manner adverbs:

32) sallah-ha Sayf kulleha bimahara

fixed-it Sayf all skillfully

'Sayf fixed it all skillfully'

33) ? sallah-ha Sayf bimahara kulleha

fixed-it Sayf skillfully all

'Sayf fixed it all skillfully'

34) akalat-ha Belgees kulleha bisagateh

ate-it Belgees all greedily

'Belgees ate it all greedily'

35) ?? akalat-ha Belgees bisagateh kulleha

ate-it Belgees greedily all

'Belgees ate it all greedily'

We need now to examine the position of these quantifier objects, which is higher than $\mathrm{vP}$, with respect to subject floating quantifiers. The examples below show this interaction in Standard Arabic:

36) akal-a l-awlaadu jamiahum kulashay binaham

ate-m the-boys all everything greedily

'The boys all ate everything greedily'

37) aslah-na l-banaatu jamiahun kulashay bimahara

fixed-f the-girls all everything skillfully

'The girl all fixed everything skillfully'

Likewise, in Sana'ani Arabic the subject quantifier usually precedes the quantifier object:

38) akal al-eyal kulluhum kulshi bisagateh

ate the-boys all everything greedily

'The boys all ate everything greedily'

39) sallah-ain al-banaat kullehen kulshi bimahareh

fixed-f the-girls all everything skillfully

'The girl all fixed everything skillfully'

The examples above show that the moved quantifier object is actually preceded by the subject floating quantifier, supporting the assumption that both the subject and the object must have vacated the vP and moved to a 
projection higher than vP and AdvP. It is to be noticed that a VOS order in this context cannot be entertained, hence the ungrammaticality of the sentences below:

40) *akal-a l-awlaadu kulashay jamiahum binaham

ate-m the-boys everything all greedily

'The boys all ate everything greedily'

41) *aslah-na 1-banaatu kulashay jamiahun bimahara

fixed-f the-girls everything all skillfully

'The girl all fixed everything skillfully'

The ungrammaticality of the sentences above when the quantifier object precedes the subject quantifier has a parallel behaviour in Sana'ani Arabic:

42) *akal l-eyal kulshi kulluhum bisagateh

ate the-boys everything all greedily

'The boys all ate everything greedily'

43) *sallah-ain al-banaat kulshi kullehen bimahareh

fixed-f the-girls everything all skillfully

'The girl all fixed everything skillfully'

The fact that we cannot have a VOS order in the sentences above, though VOS order is a possible word order in both Standard Arabic and Sana'ani Arabic, shows that the subject and object in the sentences above are not in their base position anymore and the subject must have moved to a higher projection, presumably SubjP.

\section{Adverbs and the Position of the Subject}

Another argument that can support our assumption that subjects can have more than one position postverbally comes from the interaction between postverbal subjects, objects, and manner adverbs. Ordonez (2005) argues that manner adverbs might intervene between the verb and the determinerless complement in Spanish:

44) no sabia que pintase bien cuadros.

not knew that painted well pictures

'I did not know that he painted pictures well'

45) alli dibujaba cuidadosamente paisajes.

there drew-imp carefully landscapes

'There she drew landscapes carefully'

He assumes that the manner adverbs bien and mal are usually merged to the left of the vP (Cinque 1999; Costa 1997):

46) $[$ verb.......... [ bien/mal.....[vP......DP object ] ]]]

He also argues that when objects precede these manner adverbs, the assumption is that the object must have moved to a position above these adverbs:

47) alli pinta cuadros bien.

there paints pictures well

'There he paints pictures well'

48) alli dibujaba paisajes cuidadosamete.

there drew-imp landscapes carefully

'There she drew landscapes carefully'

In this configuration, subjects that precede these objects must be in a position higher than the landing position of these objects and also higher than the position of manner adverbs (Ordonez, 2005):

49) alli pintan tus hermanos cuadros bien.

there paints your siblings pictures well

'Your siblings paint pictures well' 
50) alli dibujaba Marisa paisajes cuidadosamente.

there drew-imp Marisa landscapes carefully

'Marisa drew landscapes carefully'

Applying these assumptions to data from Standard Arabic unveils striking similarities in the behaviour of manner adverbs in these two languages. In Standard Arabic, the manner adverb can precede the object only when the latter is determinerless:

51) akal-at Belgees tufahatan binaham

ate-f Belgees apple greedily

'Belgees ate an apple greedily'

52) akal-at Belgees binaham tufahatan

ate-f Belgees greedily apple

'Belgees ate an apple greedily'

In the same way, manner adverbs in Sana'ani Arabic can precede the object of the verb only when that object does not have a determiner:

53) akal-at Belgees tufaha bisagateh

ate-f Belgees apple greedily

'Belgees ate an apple greedily'

54) akal-at Belgees bisagateh tufaha

ate-f Belgees greedily apple

'Belgees ate an apple greedily'

The examples above suggest that while the postverbal subject is to the left of the manner adverb that is positioned above $\mathrm{vP}$, the determinerless object can surface inside the vP projection. However, when the object has the determiner $a l$ 'the', it must move to the left of the manner adverb:

55) fatah-a Sayf-un al-baab-a onwatan

open-m Sayf-nom the-door-acc forcibly

'Sayf opened the door forcibly'

56) *fatah-a Sayf-un onwatan al-baab-a

open-m Sayf-nom forcibly the-door-acc

'Sayf opened the door forcibly'

Likewise, the object in Sana'ani Arabic must move to the left of the manner adverb when that object has the determiner $a l$ 'the':

57) akal-at Belgees at-tufaha bisagateh

ate-f Belgees the-apple greedily

'Belgees ate the apple greedily'

58) *akal-at Belgees bisagateh at-tufaha

ate-f Belgees greedily the-apple

'Belgees ate the apple greedily'

The interaction of the subject with manner adverbs clearly shows that subjects that precede the objects in the examples above must be in a position higher than the landing position of these objects and also higher than the position of manner adverbs.

\section{Pronouns and the Position of the Subject}

Although Standard Arabic is generally known to have a free word order where the subject can either precede or follow the verb, it should be noticed that when the subject is pronominal it must precede the verb: 
59) hiya fatah-at al-baab-a

she opened-f the-door-acc

'She opened the door'

60) *fatah-at hiya al-baab-a

opened-f she the-door-acc

'She opened the door'

However, pronominal subjects can either precede or follow verbs in Sana'ani Arabic:

61) hih fatah-at al-baab

she opened-f the-door

'She opened the door'

62) fatah-at hih al-baab

opened-f she the-door

'She opened the door'

Unlike pronominal subjects, pronominal objects in Standard Arabic are always bound, i.e., pronominal objects must be attached as a clitic either to an objective particle iya or to the verb. When a pronominal object is attached to the objective particle iya, it usually stays in its base position in the vP projection:

63) akal-at Belgees binaham iya-ha

ate-f Belgees greedily it

'Belgees ate it greedily'

64) fatah-a Sayf onwatan iya-hu

opened-m Sayf forcibly it

'Sayf opened it forcibly'

However, when there is no objective particle in Standard Arabic, the pronominal object must vacate its base position and gets encliticised into the verb, which is in a position outside the vP projection:

65) akal-at-ha Belgees binaham

ate-f-it Belgees greedily

'Belgees ate it greedily'

66) fatah-a-hu Sayf onwatan

opened-m-it Sayf forcibly

'Sayf opened it forcibly

Since Sana'ani Arabic does not have objective particles altogether, the pronominal object always shows up as a clitic on the verb:

67) akal-at-ha Belgees bisagateh

ate-f-it Belgees greedily

'Belgees ate it greedily'

68) fatah-ah Sayf biafateh

opened-it Sayf forcibly

'Sayf opened it forcibly

Two main arguments should be stressed here: the first is that the distribution of pronominal objects with manner adverbs is an important argument against a right adjunction analysis for manner adverbs. If right adjunction of adverbs is available in the sentences above, one would have to adopt the rather odd assumption that right adjunction is optional with pronominal objects but not available with DP objects. Therefore, the viable analysis is to assume that manner adverbs are based above vP (Ordonez, 2005). The second point is that in the configuration above the subject seems to be in a position outside the vP projection and above the manner adverb, presumably in spec-SubjP. 


\section{Restructuring Contexts and the Position of the Subject}

In Standard Arabic, subjects can be licensed in nonfinite contexts:

69) yureedu Sayf an yagra 1-kitaba

want Sayf to read the-book

'Sayf wants to read the book'

70) tureedu Belgees an tanama mubakiran

want Belgees to sleep early

'Belgees wants to sleep early'

Examining the possible distribution of subjects in nonfinite clauses reveals that subjects can have two different positions in these clauses, either before or after the nonfinite verb. Compare the examples above with the following examples:

71) yureedu an yagra Sayf al-kitab

want to read Sayf the-book

'Sayf wants to read the book'

72) tureedu an tanama Belgees mubakiran

want to sleep Belgees early

'Belgees wants to sleep early'

In addition, when the nonfinite clause has a modal verb, then the subject can either occur between the modal verb and the nonfinite verb or between the nonfinite verb and the complement of that verb:

73) alyoum tastatee Belgees an tulgi khitaban

today can Belgees to deliver speech

'Today Belgees can deliver a speech'

74) alyoum tastatee an tulgi Belgees khitaban

today can to deliver Belgees speech

'Today Belgees can deliver a speech'

Since the assumed specifier position of SubjP is below the final landing site of the verb in TP (Ordonez, 2005), we can represent the order in which the subject appears between the modal verb and the nonfinite verb in Standard Arabic as below:

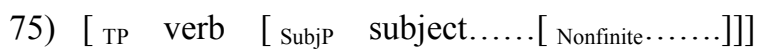

However, this representation does not explain the instances where the subject is positioned between the nonfinite verb and the complement:

76) alyoum tastatee an tulgi Belgees khitaban

today can to deliver Belgees speech

'Today Belgees can deliver a speech'

There are two different explanations here: the first is to assume that the subject 'Belgees' is in its base position in spec-vP. However, this analysis will leave us wondering at the motivation behind the subject movement in the alternative order below:

77) alyoum tastatee Belgees an tulgi khitaban

today can Belgees to deliver speech

'Today Belgees can deliver a speech'

The assumption that the subject 'Belgees' can optionally move to spec-SubjP contradicts our other assumption that the head Subj has an EPP feature that needs to be satisfied via movement of the subject to spec-SubjP.

The second explanation is to assume that the subject 'Belgees' in both word orders is in spec-SubjP; however, when the subject follows the nonfinite verb, one can assume that this nonfinite verb must have moved to a 
projection between the finite modal and SubjP (Ordonez, 2005). This explanation can be supported by the following example where an adverbial phrase is positioned between the subject and the complement:

78) tastatee an tulgi Belgees alyoum khitaban

can to deliver Belgees today speech

'Today Belgees can deliver a speech'

The adverb alyoum 'today' can be assumed to be to the left of the vP projection, hence the subject 'Belgees' must have moved above the adverbial phrase to land in spec-SubjP and the nonfinite verb must have moved as well to a position above SubjP.

Ordonez (2005) examines the possible distribution of subjects with relation to restructuring contexts in Spanish and argues that in this language subjects might appear between modals and infinitives and also between infinitives and complements of those infinitives:

79) hoy no quieren los estudiantes leer las novelas

today no want-inf the students to read the novels

'Today the students don't want to read the novels'

80) hoy no quieren leer los estudiantes las novelas

today no want-inf to read the students the novels

'Today the students don't want to read the novels'

81) hoy no deberia Maria estar cansada

today not should Maria be-inf tired

'Today Maria should not be tired'

82) hoy no deberia estar Maria cansada

today not should be-inf Maria tired

'Today Maria should not be tired'

He concludes that verbs that trigger restructuring allow main subjects to follow their infinitives and precede other complements and verbs. Further, he assumes that when the subject follows the infinitive verb it means that this infinitive verb must have moved to a functional head InfP that is positioned between the modal head and the SubjP head (Ordonez, 2005).

In Sana'ani Arabic, postverbal subjects can have two different positions with relation to nonfinite clauses, either before or after the nonfinite verb. Compare the examples below:

83) yeshti Sayf yegra l-ktab

want Sayf read-inf the-book

'Sayf wants to read the book'

84) yeshti yegra Sayf al-ktab

want read-inf Sayf the-book

'Sayf wants to read the book'

85) teshti Belgees turgud biheeneh

want Belgees sleep-inf early

'Belgees wants to sleep early'

86) teshti turgud Belgees biheeneh

want sleep-inf Belgees early

'Belgees wants to sleep early'

It is to be noticed that Sana'ani Arabic nonfinite verb lacks the typical nonfinite particle an 'to' that is prevalent in Standard Arabic. Also, DPs in Sana'ani Arabic, like all other regional varieties of Arabic, lost their case markers. 
Similar to Standard Arabic and Spanish, when the nonfinite clause in Sana'ani Arabic has a modal verb, then the postverbal subject can either surface between the modal verb and the nonfinite verb or between the nonfinite verb and the complement of that verb:

87) alyoum tester Belgees tedi khitab today can Belgees deliver-inf speech

'Today Belgees can deliver a speech'

88) alyoum tester tedi Belgees khitab today can deliver-inf Belgees speech

'Today Belgees can deliver a speech'

It is clear from the examples above that the verbs which trigger restructuring in Sana'ani Arabic allow postverbal subjects to precede or follow their nonfinite verb. I assume that when the subject follows the nonfinite verb it means that this nonfinite verb must have moved to a functional head that is positioned between the modal head and the SubjP head, along lines proposed in Ordonez (2005).

\section{Conclusion}

In this paper, I have examined the position(s) of postverbal subject in Standard Arabic and Sana'ani Arabic in order to map the TP layer of these two Semitic languages and characterize the inventory of functional heads that can appear between the vP and TP heads. This investigation has led us to assume that there are two different positions for the postverbal subject in these languages: i) spec-vP; and ii) spec-SubjP. This amounts to saying that there is a specifier position of a functional head Subj that is the landing site of higher postverbal subjects. It is also implied that this head has an EPP feature to trigger the movement of the subject to its specifier position. Multiple diagnostic tests are administered to support our analysis. These tests include the investigation of the position of the postverbal subject and its interaction with object quantifiers, floating subject quantifiers, adverbial phrases, pronominal clitics, and restructuring contexts.

\section{Acknowledgement}

I gratefully acknowledge the financial support and generosity of the Deanship of Scientific Research, Qassim University, KSA, without which the present study could not have been completed.

\section{References}

Alexiadou, A., \& Anagnostopoulou, E. (2001). The Subject-in-situ generalization and the role of case in drining Computations. Linguistic Inquiry, 32, 193-231. http://dx.doi.org/10.1162/00243890152001753

Aoun, J., Benmamoun, E., \& Choueiri, L. (2010). The syntax of Arabic. Cambridge: Cambridge University Press.

Aoun, J., Benmamoun, E., \& Sportiche, D. (1994). Agreement, word order, and conjunction in some varieties of Arabic. Linguistic Inquiry, 25(2), 195-220.

Belletti, A. (2004). Aspects of the low IP area. In L. Rizzi (Ed.) The structure of CP and IP. Oxford: Oxford University Press.

Benmamoun, E. (2000). The feature structure of functional categories: A comparative study of Arabic dialects. Oxford: Oxford University Press.

Biberauer, T., \& Roberts, I. (2010). Subjects, tense and verb-movement. In Theresa Biberauer et al. (Eds.), Parametric variation: null subjects in minimalist theory. Cambridge: Cambridge University Press.

Boeckx, C. (2008). Elementary syntactic structures. A minimalist inquiry. Ms, Harvard University.

Cardinaletti, A. (1997). Subjects and clause structure. In L. Haegeman (Ed.), The New Comparative Syntax (pp. 33-63). London: Longman..

Cardinaletti, A. (2004). Towards a cartography of subject positions. In L. Rizzi, (Ed.), The Structure of CP and $I P$. Oxford: Oxford University Press.

Chomsky, N. (2001). Derivation by phase. In M. Kenstowicz (Ed.), Ken Hale: A Life in Language (pp. 1-52). Cambridge, MA: The MIT Press.

Chomsky, N. (2004). Beyond explanatory adequacy. In A. Belletti (Ed.), Structures and Beyond. The Cartography of Syntactic Structures (Vol. 3, pp. 104-131). Oxford: OUP. 
Chomsky, N. (2005). On phases. Ms. MIT.

Chomsky, N. (2007). Approaching UG from below. In U. Sauerland \& H.-M. Gartner (Eds.), Interfaces + Recursion = Language? Chomsky's Minimalism and the View from Syntax-semantics (pp. 1-30). Berlin: Mouton de Gruyter.

Chomsky, N. (2008). On phases. In C. Otero et al. (Eds.), Foundational Issues in Linguistic Theory. Essays in Honor of Jean-Roger Vergnaud (pp. 134-166). Cambridge MA: The MIT Press. http://dx.doi.org/10.7551/mitpress/9780262062787.003.0007

Cinque, G. (1999). Adverbs and functional heads. Oxford: Oxford University Press.

Cinque, G. (2004). Restructuring and functional structure In A. Belletti (Ed.), Structures and Beyond. The Cartography of Syntactic Structures (Vol. 3, pp. 132-191). Oxford: OUP.

Cinque, G. (2006). Restructuring and Functional Heads. The Cartography of Syntactic Structures (Vol. 4). Oxford: OUP.

Costa, J. (1997). On the behavior of Adverbs in Sentence-Final Context. The Linguistic Review, 43-68.

Costa, J. (2000). Word order and discourse-configurationality in European Portuguese. In J. Costa (Ed.), Portuguese Syntax: New Comparative Studies (pp. 94-115). Oxford: OUP.

Costa, J. (2002). VOS in Portuguese: Arguments against an analysis in terms of remnant movement. In A. Alexiadou et al. (Eds.), Dimensions of Movement (pp. 69-89). Amsterdam: John Benjamins. http://dx.doi.org/10.1075/la.48.05cos

D’Alessandro, R., \& Roberts, I. G. (2008). Movement and agreement in Italian past participles and defective phases. Linguistic Inquiry, 39, 477-491. http://dx.doi.org/10.1162/ling.2008.39.3.477

Davies, W., \& Dubinsky, S. (2001). Functional architecture and the distribution of subject properties. In W. Davies \& S. Dubinsky (Eds.), Objects and other Subjects (pp. 247-280). Dordrecht: Kluwer. http://dx.doi.org/10.1007/978-94-010-0991-1_10

Fassi Fehri, A. (1993). Issues in the structure of Arabic clauses and words. Dordrecht: Kluwer. http://dx.doi.org/10.1007/978-94-017-1986-5

Fassi Fehri, A. (2012). Key features and parameters in Arabic grammar. Amsterdam: John Benjamins. http://dx.doi.org/10.1075/la.182

Haegeman, L. (1994). Verb raising as verb projection raising: some empirical problems. Linguistic Inquiry, 23, 509-522.

Haegeman, L. (1998). V-Positions and the middle field in West Flemish. Syntax, 1, 259-299. http://dx.doi.org/10.1111/1467-9612.00010

Haegeman, L. (2000). Negative inversion, the Neg criterion and the structure of CP. In L. Horn \& Y. Kato (Eds.), Negation and Polarity (pp. 29-69). Oxford: Oxford University Press.

Holmberg, A. (1986). Word Order and Syntactic Features in Scandinavian Languages and English (Doctoral dissertation), University of Stockholm.

Hornstein, N. (2009). A Theory of Syntax: Basic Operations and the Minimalist Program. Cambridge: CUP.

Kayne, R. (1975). French Syntax: the transformational cycle. Cambridge: MIT Press.

Kayne, R. (1991). Romance Clitics, Verb Movement and PRO. Linguistic Inquiry, 22, 647-686.

Kayne, R. (1994). The Antisymmetry of Syntax. Cambridge, Mass.: MIT Press.

Kayne, R. (1998). Overt vs. covert movements. Syntax, 1, 128-191. http://dx.doi.org/10.1111/1467-9612.00006

Kayne, R. (2000). Parameters and Universals. Oxford: Oxford University Press.

Kayne, R., \& Pollock, J.-Y. (2001). New Thoughts on Stylistic Inversion. In A. Hulk \& J.-Y. Pollock (Eds.), Subject Inversion in Romance and the Theory of Universal Grammar (pp. 107-162). Oxford: Oxford University Press.

Koopman, H., \& Dominique, S. (1991). The position of subjects. Lingua, 85, 211-258. http://dx.doi.org/10.1016/0024-3841(91)90022-W

Lasnik, H., \& Saito, M. (1992). Move $\alpha$ : Conditions on its Applications and Outputs. Cambridge MA: The MIT Press. 
McCloskey, J. (1997). Subjects and subject positions. In L. Haegeman (Ed.), Elements of Grammar (pp. 197-235). Dordrecht: Kluwer. http://dx.doi.org/10.1007/978-94-011-5420-8_5

Ordonez, F. (1998). Post-verbal asymmetries in Spanish. Natural Language and Linguistic Theory, 16, 313-346. http://dx.doi.org/10.1023/A:1006051703562

Ordonez, F. (2005). Cartography of postverbal subjects in Spanish and Catalan. Ms. SUNY, Stony Brook.

Ouhalla, J. (1994). Verb movement and word order in Arabic. In D. Lightfoot \& N. Hornstein (Eds.), Verb movement (pp. 41-72). Cambridge: Cambridge University Press. http://dx.doi.org/10.1017/CBO9780511627705.004

Pesetsky, D., \& Torrego, E. (2004). Tense, Case, and the nature of syntactic categories. In J. Gueron \& J. Lecarme (Eds.), The Syntax of Time (pp. 495-537). Cambridge MA: The MIT Press.

Pesetsky, D., \& Torrego, E. (2007). The syntax of valuation and the interpretability of features. In S. Karimi et al. (Eds.), Phrasal and Clausal Architecture. Syntactic Derivation and Interpretation (pp. 262-294). Amsterdam: John Benjamins. http://dx.doi.org/10.1075/la.101.14pes

Rizzi, L. (1997). The fine structure of the left periphery. In L. Haegeman (Ed.), Elements of grammar: Handbook in generative syntax (pp. 281-337). Dordrecht: Kluwer. http://dx.doi.org/10.1007/978-94-011-5420-8_7

Rizzi, L. (2004). On some properties of subjects and topics. Ms. University of Siene.

Rizzi, L. (Ed.). (2004). The Structure of CP and IP. Oxford \& New York: Oxford University Press.

Rizzi, L., \& Shlonsky, U. (2005). Strategies of subject extraction. Ms. University of Siena and University of Geneva.

Rizzi, L., \& Slonshky, U. (2007). Strategies of subject extraction. In U. Sauerland \& H-M. Gartner (Eds.), Interfaces + Recursion = Language? Chomsky's Minimalism and the View from Syntax-semantics (pp. 115-160). Berlin: Mouton de Gruyter.

Roberts, I. (2010). Head movement and minimalist program. Ms. Downing College, University of Cambridge.

Ryding, K. C. (2005). A reference grammar of Modern Standard Arabic. Cambridge: Cambridge University Press. http://dx.doi.org/10.1017/CBO9780511486975

Shlonsky, U. (1997). Clause structure and word order in Hebrew and Arabic: An essay in comparative Semitic syntax. Oxford: Oxford University Press.

\section{Copyrights}

Copyright for this article is retained by the author(s), with first publication rights granted to the journal.

This is an open-access article distributed under the terms and conditions of the Creative Commons Attribution license (http://creativecommons.org/licenses/by/3.0/). 